\title{
INTRODUCTION
}

Economics at the A Level is divided into two broad areas of study: microeconomics and macroeconomics. They differ in terms of the units being analysed.

In Microeconomics, the units of analysis are the individuals and firms, which make up the players in the markets for various goods and services. Examples of what is studied includes the market price and quantity of a good and the efficiency of markets in terms of the allocation of resources.

For Macroeconomics, the unit of analysis is the study of the economy as a whole. An example of what is studied would include the performance of the Singapore economy in terms of growth, inflation, unemployment, and the balance of payments.

$\operatorname{Definition}(s)$ :

Microeconomics is the study of economic behaviour of individuals and firms.

Macroeconomics is the study of the economy as a whole.

\section{Positive Economics and Normative Economics}

All economic issues, regardless of whether they are microeconomics or macroeconomic issues, have two aspects to be analysed — the positive aspect and the normative aspect.

The positive aspect is concerned with facts and cause-and-effect relationships. This includes the development and testing of theories. This is the aspect of Economics that we term "valuefree" economics. The idea of "value-free" economics will be better understood in contrast to "values-based" normative economics which is described in the following paragraph. Positive economic statements are distinguished by whether they can be tested to be true or false. For example, "an increase in the goods and services tax (GST) from 5\% to 7\% would reduce consumption expenditure by $3 \%$ " is a positive economic statement. One could collect data and prove whether the statement is true. In other words, positive economics is objective.

In contrast, the normative aspect of economics involves making value judgements about what "should be". This could be in relation to what economic outcomes are desirable for society or what policy measure(s) ought to be adopted. Normative economic statements cannot be judged to be objectively true or false. Instead, whether one agrees with a normative economic statement is subject to one's value system. For example, "the government should prioritise the welfare of the low-income households above the middle-income households" is a normative economic statement. Whether one agrees with the statement depends on one's view of what economic fairness is. 
Positive and normative economics are complementary. For example, in deciding whether to raise taxes on the middle-income households, to provide more subsidies to the lowincome households, the government needs to analyse the effects of raising the tax rates on the welfare of the middle-income households and the effects of subsidies on the welfare of the low-income households. Both of these involve positive economic analysis. At the same time, the government must also answer the normative economic question of the extent to which the welfare of the low-income households should be prioritised over that of middleincome households. The two types of economics complement each other because normative economics guides the government in determining the ideal extent of transferring welfare from one group to another, and positive economics informs them of how effective their policy would be in doing so. Similarly, for the General Certificate of Education (GCE) A Level, candidates are expected to apply positive economic analysis to complement normative economic judgements.

Definition(s):

Positive economics is the branch of economics that studies facts and cause-and-effect relationships. It includes the development and testing of economic theories.

Normative economics is the branch of economics that expresses value judgements about economic fairness or what the outcome of the economy and policy measure(s) should be. 